\title{
PRZECIWDZIAŁANIIE STYGMATYZACJI CHORYCH PSYCHICZNIE W PRAKTYCE PIELĘGNIARSKIEJ
}

\author{
ANTI-STIGMATIZING ACTIVITIES OF MENTALLY ILL PATIENTS IN NURSERY PRACTICE \\ Piotr Wojda
}

LVR-Klinik Köln Akademisches Lehrkrankenhaus der Universität zu Köln

https://orcid.org/0000-0003-1266-486X

DOI: https://doi.org/10.20883/pielpol.2020.5

\begin{abstract}
STRESZCZENIE
Stygmatyzacja jest jedną z przeszkód w leczeniu i odzyskiwaniu zdrowia psychicznego osób chorych psychicznie. W artykule przedstawiono przyczyny i mechanizmy stygmatyzacji oraz ich następstwa dla osób napiętnowanych. Główną część artykułu stanowi opis działania pielęgniarskiego podejmowanego w celu poprawy wizerunku osób z kryzysem psychicznym w społeczeństwie. Działania edukacyjne skierowane do wybranych grup docelowych powinny poprawić wiedzę społeczeństwa na temat symptomatologii, przyczyn i opcji leczenia chorób psychicznych. Większa świadomość powinna z kolei znieść uprzedzenia i negatywne postrzeganie oraz ułatwić reintegrację społeczną osób cierpiących na choroby psychiczne.
\end{abstract}

SŁOWA KLUCZOWE: stygmatyzacja choroba psychiczna, chory psychicznie, wykluczenie społeczne, pielęgniarka.

\section{Rodzaje stygmatyzacji}

Bycie chorym psychicznie oznacza nie tylko stan biologiczny organizmu, ale również sytuację społeczną chorego. Choroba niesie ze sobą zmiany w życiu każdej osoby i jej rodziny, co wymaga modyfikacji codziennych zachowań i uniemożliwia realizację celów społecznych. Według socjologa Talcotta Parsonsa choroba jest stanem niepożądanym, gdyż zaburza wywiązywanie się jednostki z narzuconych przez grupę i społeczeństwo obowiązków [1]. Choroba zakłóca społeczne wypełnianie ról, co może prowadzić do dysfunkcjonalności grupy. Społeczeństwo, żeby mieć wpływ na funkcjonowanie i zachowania osób chorych, stworzyło rolę chorego. Istnieje zatem wzór choroby, który odpowiada społecznym oczekiwaniom. Niektóre z chorób zaś prowadzą do stygmatyzacji osób nią dotkniętych, co wiąże się z odrzuceniem społecznym.

Stygmat jest cechą dyskredytującą, która pozwala odróżnić jednostkę niepełnowartościową, a zatem mniej pożądana w grupie [2]. Stygmatyzacja szkodzi chorym

\begin{abstract}
Stigma is one of the obstacles in the treatment and regaining the mental health of people with mental illnesses. The article presents the causes, mechanisms of stigmatization and consequences for stigmatized people. The main part of the article is nursing activities undertaken to improve the image of people with a mental crisis in the community. Public information programs and educative measures aimed at selected target groups should improve the public's knowledge regarding symptomatology, causes, and treatment options for mental disorders. Improved knowledge should in turn abolish prejudice and negative perceptions and facilitate the social reintegration of those suffering from mental illnesses.
\end{abstract}

KEYWORDS: stigmatization mental illness, mentally ill, social exclusion, nurse.

wielowymiarowo. Stygmat pogarsza jakość życia, destrukcyjnie wpływa na relacje międzyludzkie i obniża poczucie własnej wartości [3]. Wyłączenie chorego z życia społecznego, które przestaje zabezpieczać jego podstawowe potrzeby, prowadzi do podejmowania działań kompensacyjnych, często o charakterze dewiacyjnym.

Choroba psychiczna we współczesnych społeczeństwach nadal jest przyczyną naznaczenia piętnem inności. Większe koszty utrzymania związane z wydatkami na pomoc medyczną, konieczność rezygnacji z pracy zarobkowej spychają takie osoby na margines ekonomiczny. Wraz ze stopniowym zubożeniem dochodzi do wycofywania się z innych aspektów życia społeczno-towarzyskiego i kulturowego. Pacjent, któremu przypisano stygmatyzującą cechę, stopniowo zaczyna wierzyć w bycie innym, a zatem gorszym człowiekiem.

Napiętnowanie jest przypisaniem krzywdzących cech osobie lub całej grupie osób [3]. Słowo piętno odnosi się współcześnie do cechy, która stygmatyzuje jednostkę i w ten sposób daje znak innym, że posiada 
jakieś cechy kulturowo i społecznie nie do zaakceptowania.

Wg B. G. Link i J. C. Phelan naznaczenie może zaistnieć pod warunkiem jednoczesnego wystąpienia czterech elementów [5]: wyodrębnienia i nazwania różnicy między ludźmi, powiązania tych odrębności z cechami negatywnymi, oddzielenia ,nas” od ,nich”, pozbawienia pozycji społecznej i wykluczenia tak wyodrębnionej jednostki.

Z napiętnowaniem wiąże się stereotypowe myślenie na temat określonego zjawiska [6]. Stereotyp jest zbiorem niepotwierdzonych, nieuzasadnionych sądów o danej grupie. Na temat chorych psychicznie funkcjonuje kilka stereotypów, np.: jest niebezpieczny, nieprzewidywalny, ponosi odpowiedzialność za swój stan, jest niezdolny do pełnienia ról społecznych, cierpi na chorobę oporną na leczenie lub nieuleczalną [7, 8].

Negatywny stereotyp osoby chorej psychicznie w społeczeństwie ogranicza możliwość tworzenia relacji interpersonalnych, wpływa na postrzeganie własnej osoby, obniżenie poczucia własnej wartości, obniżenie szans na pracę oraz na znalezienie partnera i udane życie seksualne $[9,10,11]$. Stereotypy te znajdują potwierdzenie w badaniach M. Freidla i wsp. [12], z których wynika, że ponad $50 \%$ pacjentów psychiatrycznych jest zdania, że większość ludzi postrzega ich jako mniej inteligentnych, mniej wiarygodnych i traktuje ich mniej poważnie. Przekonanie chorych o ich mniejszej przydatności prowadzi do samostygmatyzacji. Wykazano, że pacjenci, którzy nie przepisują własnych problemów chorobie psychicznej (i w ten sposób odrzucają etykietę chorego psychicznie) mają wyższy wskaźnik jakości życia, niższe poczucie napiętnowania oraz wyższe poczucie własnej wartości niż ci, którzy odbierają siebie jako chorych psychicznie. Należy wspomnieć, że konsekwencje płynące z napiętnowania, takie jak utrata poparcia społecznego i bezrobocie, stanowią same przez się silne czynniki ryzyka chorób psychicznych. Z badań przeprowadzonych przez A. Cechnickiego i A. Bielańską [6] wynika, że na proces samonapiętnowania mają wpływ czynniki demograficzno-społeczne. Kobiety częściej niż mężczyźni uważają, że osoby zdrowe nie chcą się wiązać z tymi, którzy chorują lub chorowali psychicznie. Osoby lepiej wykształcone w celu ochrony siebie przed piętnem ukrywały fakt swojej choroby przed otoczeniem. Poczucie piętna jest większe również u osób, które są częściej hospitalizowane. Badani rehospitalizowani częściej doświadczali odrzucenia przez bliskich i innych oraz mieli problemy na rynku pracy. Wyższy status socjoekonomiczny rodziców również prowadzi do poczucia napiętnowania, gdyż wiąże się to z większą świadomością tego, co mają do stracenia [12].

\section{Czynniki piętnujące chorego psychicznie}

Czynniki, które mają wpływ na napiętnowanie osoby chorującej psychicznie, można podzielić na związane z osobą dotkniętą chorobą (objawy chorobowe, samostygmatyzacja, niskie kompetencje społeczne, niskie wykształcenie, pozycja społeczna) i socjologiczne (odrzucenie przez grupę, dyskryminacja, stereotypy).

Objawy choroby psychicznej mogą prowadzić do naznaczenia, jeśli skutkują naruszeniem porządku społecznego poprzez uzewnętrznianie się ,,inności” w sposobie poruszania, ubierania, stylu życia czy dostosowania afektu do sytuacji. Naruszenie reguł obowiązujących w danym społeczeństwie wiąże się z przypisaniem sprawcy etykiety, po czym dochodzi do powiązania jej ze stereotypem, a więc nadania cech charakterystycznych dla danej etykiety. Społeczeństwo czerpie wiedzę na temat chorób psychicznych najczęściej z mediów, nieprofesjonalnej prasy oraz fikcji filmowej $[7,12]$. Negatywne postrzeganie chorych psychicznie jest wzmacniane i rozpowszechniane przez środki masowego przekazu $[8,12]$. W filmach osoby chore psychicznie przedstawione są wyjątkowo niekorzystnie. Jawią się jako osoby złe, skore do agresji i morderstw. Analiza seriali telewizyjnych wykazała, że na ekranie osoby z zaburzeniami psychicznymi stosują przemoc dziesięciokrotnie częściej niż osoby zdrowe oraz do dwudziestu razy częściej niż w rzeczywistości (9). Badanie przeprowadzone przez niemieckich badaczy zobrazowały istotny wpływ mediów na postawę wobec chorych psychicznie. Po nagłośnieniu przez prasę zamachów na polityków przeprowadzonych przez osoby chore psychicznie doszło do znacznego wzrostu postawy niechęci i dystansu wobec osób ze schizofrenią [10]. Media nie tylko wzmacniają stereotypowe postrzeganie osób chorych psychiczne, ale również wpajają i uczą wypaczonego postrzegania ludzi dotkniętych kryzysem psychicznym. W ponad 65\% emitowanych kreskówek i filmów dla dzieci i młodzieży osoby chore psychicznie były przedstawione jako nieobliczalne, niosące zniszczenie, z którymi należy walczyć i które należy ukarać [11, 12]. Osobisty kontakt z osobą chorą zmniejsza uprzedzenia i pozwala osobiście zweryfikować początkowe przekonania. Osoby, które mają zawodowy kontakt z chorymi psychicznie lub mają takiego chorego w najbliższym otoczeniu, są mniej skore do negatywnego osądu [12].

Rozpoznanie choroby psychicznej, a więc postawienie diagnozy, ma cechy zbieżne ze stygmatem. Poprzez diagnoze jednostka zostaje zaklasyfikowana do grupy ludzi o nieakceptowanych cechach [13]. Stopień napiętnowania osób obciążonych chorobą psychiczna jest zależny nie tylko od diagnozy, ale od przeświadczenia otoczenia o odpowiedzialności chorego za swoją cho- 
robę. Badania wykazały, że 78\% respondentów uważało, że osoby uzależnione od alkoholu i narkotyków same są odpowiedzialne za swoją chorobę. Poziom negatywnych postaw był siedmiokrotnie mniejszy wobec chorych, których nie obarczono odpowiedzialnością za swoją chorobę, np. na depresję lub schizofrenię [14].

Istotnym czynnikiem stygmatyzującym jest wszystko, co związane z psychiatrią. Psychiatria jest dyscypliną, na której się oszczędza, w którą się nie inwestuje. Szpitale psychiatryczne mieszczą się często na obrzeżach miast, w starych, zakratowanych budynkach oddalone są od innych placówek medycznych. Szpital psychiatryczny jawi się jako jednostka ubezwłasnowolniająca, stosująca praktyki naruszające godność ludzką, gdzie pacjent doznaje wyłącznie cierpienia i poniżenia. W odbiorze społecznym miejsca takie budzą grozę. Środki, jakie stosuje się w leczeniu, niosą ze sobą widoczne objawy uboczne [15]. Przez lata w krajach komunistycznych psychiatria wykorzystywana była do celów represyjnych, eliminowania niewygodnych przeciwników systemu poprzez przypisanie im etykiety niepoczytalnego i niebezpiecznego dla otoczenia [16, 25]. Psychiatra był kojarzony z wiernym wykonawcą zaleceń aparatu władzy [16, 21, 25].

\section{Następstwa stygmatyzacji dla osób z kryzysem psychicznym}

W odniesieniu do chorujących psychicznie pojęcie stygmatyzacji obejmuje kilka negatywnych postaw prezentowanych w społeczeństwie. Najczęściej spotykane jest dystansowanie się poprzez unikanie wchodzenia w formalne i nieformalne kontakty. $Z$ badań prowadzonych na szeroką skalę wynika, że $60 \%$ ankietowanych nie wynajęłoby mieszkania osobie chorej psychicznej, a prawie $35 \%$ nie chciałoby mieć takiego sąsiada. Jedna trzecia badanych nie widzi chorego psychicznie w roli kolegi [16]. Kolejną negatywną postawą otoczenia jest dewaluacja i rozpowszechnianie negatywnych opinii o napiętnowanej grupie. Prawie 50\% respondentów było przekonanych, że inni myślą źle o osobach, które były u psychiatry, a tylko 53\% ankietowanych twierdziła, że osoby chore psychicznie uważane są za tak samo inteligentne jak osoby zdrowe [17].

Szczególną formą negatywnego nastawienia do osób z chorobą psychiczną jest delegitymizacja, czyli prawne ograniczenie funkcjonowania w pewnych obszarach życia społecznego. Chorzy psychicznie niechętnie widziani byli w zawodach wiążących się z ponoszeniem odpowiedzialności za innych. Z badań CBOS wynika, że ankietowani nie zgodziliby się, żeby osoba po kryzysie psychicznym miała zajmować się ich dziećmi - być ich opiekunem (85\%) lub nauczycielem (82\%). Nieco mniej osób sprzeciwiłoby się temu, by były pacjent szpitala psychiatrycznego miał zostać ich lekarzem (76\%), burmistrzem lub wójtem w ich gminie (59\%), szefem w pracy $(46 \%)[18,24]$.

Niemal wszyscy ankietowani pracodawcy (95\%) nie widzą możliwości zatrudnienia na jakimkolwiek stanowisku osób cierpiących na schizofrenię, a ponad 10\% ankietowanych nigdy nie zatrudniłoby osoby z chorobą psychiczną. Zdecydowana większość chorych (84\%) pozostaje bez pracy, są one niechętnie zatrudniane i w pierwszej kolejności zwalniane [19].

Poza tym chorzy napotykają trudności w zawarciu związku małżeńskiego, ponieważ w art. 12 Kodeksu rodzinnego i opiekuńczego nadal widniej zapis, że „Nie może zawrzeć małżeństwa osoba dotknięta chorobą psychiczną albo niedorozwojem umysłowym".

Osoby chorujące psychicznie żyją znacznie krócej niż przedstawiciele populacji ogólnej. Fakt ten jest związany z częstszymi samobójstwami, podwyższonym ryzykiem chorób układu sercowo-naczyniowego, chorób nowotworowych, cukrzycy i gorszym dostępem do opieki zdrowotnej. Zostało dowiedzione, że osoby z diagnozą psychiatryczną muszą dłużej oczekiwać na transplantację organów. W populacji obciążonej chorobami sercowo-naczyniowymi pacjenci ze schizofrenią mają rzadziej zlecane badania cholesterolu, rzadziej są kierowani na wizyty do specjalistów i poddawani zabiegom operacyjnym, jak np. pomostowaniu aortalnowieńcowemu (tzw. by-pasy) czy implantacji kardiostymulatora (tzw. rozrusznik serca) [20].

Najbardziej drastyczną formą eliminowania z życia społecznego osób napiętnowanych jest eksterminacja, której efekty widoczne były w czasie II wojny światowej, gdy naziści eliminowali chorych poprzez zagłodzenie lub zagazowanie [21]. Ograniczenie populacji chorych psychicznie było długo propagowane. Prawo pozwalające na sterylizację chorych psychicznie istniało w Szwecji do 1972 r., w Japonii do 1996 r.

Stygmatyzacja ma nie tylko wymiar społeczny, ale również jednostkowy. Oddziaływanie grupy jest tak duże, że posiadacz niepożądanej cechy sam się napiętnowujeiodsuwanamargines. Chora, obserwującotoczenie i odbierając negatywne sygnały dotyczące własnej osoby, stopniowo wyrabia w sobie fałszywe przekonanie o sobie. Napiętnowany zaczyna postępować i zachowywać tak, jak oczekuje od niego grupa społeczna. Trudno jest im samym uwolnić się od społecznych stereotypów i uprzedzeń z chwilą rozpoznania choroby. Poczucie bycia odmiennym powoduje, że oczekują przejawów dyskryminacji, podzielają nieprzychylne opinie i zbyt dobrze rozumieją zachowania swojej społeczności (autostygmatyzacja). Mogą czuć się winni, że zachorowali, a ich krewni są napiętnowani społecznie z ich powodu. Link i wsp. wykazali, że chorzy najbardziej odczuwający styg- 
matyzację mieli 7-9 razy niższą samoocenę w porównaniu z doświadczającymi napiętnowania w mniejszym stopniu [22, 23, 24]. Posiadanie piętna psychicznie chorego prowadzi stopniowo do wykluczenia społecznego, czyli do niepodejmowaniu zwyczajowej i społecznie akceptowanej aktywności życiowej. Wydatki związane z leczeniem, rehabilitacją, konieczność rezygnacji z pracy przez chorego prowadzą do postępującej pauperyzacji i wykluczania ekonomicznego. Osoba dotknięta chorobą psychiczną musi zrezygnować z wielu „,przyjemności”, na które kiedyś mogła sobie pozwolić $[25,26]$.

\section{Zapobieganie stygmatyzacji pacjentów psychiatrycznych w codziennej praktyce pielęgniarskiej}

Przeciwdziałanie stygmatyzacji powinno obejmować wiele wymiarów, począwszy od edukacji do jawnego sprzeciwu wobec krzywdzącego zachowania wobec chorych. Ważnym filarem kształtującym postawy antystygmatyzujące jest edukacja zakrojona na szeroką skalę. Adresatami powinny być zarówno dzieci, których poglądy dopiero co się kształtują, jak i osoby dorosłe, które ze względów zawodowych mają kontakt z chorymi psychicznie lub wpływają na kształtowanie opinii publicznej (dziennikarze, służby publiczne itp.). Wcześnie rozpoczęta edukacja prowadzi do kształtowania pozytywnych postaw wobec osób chorych psychicznie. Pozytywne nastawienie poznawcze wyraża się przede wszystkim poprzez uznanie, że przedmiotem poznania jest człowiek, a nie tylko jego choroba, dostrzeganie zalet, możliwości i osiągnięć osób chorych [27, 28]. Osoby z pozytywnym nastawieniem nie mają problemu z nawiązywaniem kontaktu z osobą chorą, a kontakt z nią nabiera dla danej osoby większej wartości. Kontakt chorych dzieci ze zdrowymi niesie obopólną korzyść. Dzieci z ograniczeniami kognitywnymi przez naśladowanie znacznie szybciej opanowują nawyki prawidłowego zachowania w codziennych sytuacjach życiowych. Poza tym sprawni rówieśnicy zachęcają znacznie lepiej niż dorośli do podejmowania nowych, czasem bardzo trudnych zadań. Natomiast dzieci zdrowe rozwijają postawę szacunku i akceptacji dla innych i uczą, jak zachować się w stosunku do ludzi w potrzebie. Akceptacja inności pozwala budować wspólnotę szkolną, a następnie lokalną bez konfliktów i uprzedzeń. Uczniowie podczas edukacji powinni mieć możliwość krytycznego spojrzenia na swoje postawy oraz przyswojenie sobie umiejętności prowadzenia dialogu z osobami, których światopogląd jest sprzeczny z ich własnym [29]. Zajęcia edukacyjne można przeprowadzić według poniższych scenariuszy.

\section{Scenariusz zajęć dla klas 3-4 szkoły podstawowej}

Temat: Jesteśmy różni, ale to dobrze (czas trwania 45 min.). Cel ogólny: kształtowanie w uczniach poczucia akceptacji inności i przekonania, że każdy jest równy.

Cele szczegółowe: uczniowie dostrzegają różnice i podobieństwa między ludźmi; uczniowie potrafią zaakceptować inność i wyróżnić ją w pozytywnym znaczeniu; uczniowie wiedzą, że kogoś „innego" nie można dyskryminować, odrzucać i nie można mu dokuczać; uczniowie wyrażają swoje spostrzeżenia i emocje związane z odmiennością; uczniowie poznają znaczenie pojęć: dyskryminacja, tolerancja, akceptacja, równość. Metody pracy: dyskusja, praca grupowa, praca indywidualna.

Środki pomocnicze: tablica, flamastry, kredki, piłka, film. Przebieg zajęć. 1. Wstęp. Przedstawienie się uczestnikom, zapoznanie z tematem zajęć (15 min.).

2. Praca indywidualna. Pielęgniarka podaje dziecku piłkę i pyta: Różnię się od ciebie, ponieważ...? Po udzieleniu odpowiedzi, dziecko przekazuję piłkę innemu, zadając to samo pytanie i tak dalej, do ostatniego uczestnika. 3. Praca w grupie. Pielęgniarka dzieli dzieci na grupy. Rozdaje przybory piśmiennicze, kartki papieru. Przedstawia krótki 10-minutowy film z różnymi postaciami ludzi, którzy różnią się wzrostem, kolorem skóry i tym, jak się ubierają, jak się poruszają, jak mówią i się zachowują (pośród nich znajduje się osoba z zespołem Downa). Prosi o napisanie na kartkach odpowiedzi na pytania: Co jest dobrego w tym, że ludzie się różnią? W czym różnice są przydatne? Po 15 min. pracy dzieci prezentują wyniki. Pielęgniarka koryguje i uzupełnia spostrzeżenia. Omawia poprawne postawy wobec innych ludzi. Nagradza pochwałą poprawne spostrzeżenia.

\section{Scenariusz zajęć antystygmatyzujących w szkole ponadpodstawowej}

Temat: Prawda i mity o chorych psychicznie (czas trwania 45 min.).

Cel ogólny: Ćwiczenie ma na celu przełamywanie negatywnych stereotypów na temat chorych psychicznie.

Cele szczegółowe: skonfrontowanie uczniów z nieprawdziwymi informacjami o chorych psychicznie; dostrzeżenie potrzeb osób chorych psychicznie; korygowanie negatywnych postaw wobec chorych psychicznie i niepowielanie nieprawdziwych opinii o chorych.

Metody pracy: pogadanka, dyskusja, praca w grupach. Środki: tablica, kartki papieru, przybory do pisania. 
Przebieg: 1. Wstęp. Przedstawienie się uczestnikom, zapoznanie z tematem zajęć (10 min.). 2. Rozwinięcie: Na tablicy pielęgniarka zapisuje słowo „FAKTY”, a następnie prosi o podanie skojarzeń, przekonań, jakie nasuwają się uczniom na temat osób chorych psychicznie. Najczęściej podawane stwierdzenia zapisuje na tablicy pod słowem „FAKTY” (30 min.). Przykładowe stwierdzenia: Chorzy psychicznie są niebezpieczni dla innych ludzi. (W celu obalenia tego stereotypu pielęgniarka przytacza badania naukowe.) Chorzy psychicznie są mniej inteligentni od innych. (Przedstawienie znanych osób chorych psychicznie, np. John Nash pierwowzór bohatera „Piękny umysł”, Isaac Newton, Ludwig van Beethoven). Chorzy psychicznie są bezużyteczni dla społeczeństwa. (Podanie przykładów funkcjonowania publicznego osób chorych, ich wkładu w kulturę i życie społeczne, np. Catherine Zeta-Jones, Heath Ledger, Kora, Nietzche, Abraham Lincoln).

Uczniowie powinni odnieść się do wypisanych przez pielęgniarkę twierdzeń. Wskazać, dlaczego są one nieprawdziwe. Zastanowić się, jakie mogą być konsekwencje takich uogólnień. Należy zadać uczniom pytania: Skąd czerpią informacje o zachowaniu chorych psychicznie? Czy mieli okazję poznać kogoś z kryzysem psychicznym?

Uczniowie powinni sobie uświadomić, iż budują swoje stereotypy i uprzedzenia na podstawie zasłyszanych i niesprawdzonych informacji. Jeśli uczniowie mają negatywne doświadczenia osobiste, to należy ich skłonić do refleksji, dlaczego uważają, że ich doświadczenia dotyczą całej grupy?

Zakończenie: Pielęgniarka nagradza, pochwala pozytywne spostrzeżenia i zaangażowanie (5 min.).

\section{Działania edukacyjne pielęgniarek i pielęgniarzy}

Osoby pracujące w zawodzie pielęgniarki/ pielęgniarza powinny bardziej się zaangażować w działania edukacyjne skierowane do większego grona odbiorców, jak np. kampanie społeczne [30]. Międzynarodowa Rada Pielęgniarek ordynuje kilka reguł w celu oddziaływania na politykę zdrowotną i lokalną społeczność:

1. Poznanie sytuacji zdrowotnej społeczeństwa, społeczności lokalnej: jakie choroby psychiczne występują najczęściej i jakie implikacje społeczne niosą.

2. Publikowanie własnych prac poruszających problematykę zdrowia psychicznego. Przedstawianie pomysłów na rozwiązywanie aktualnych problemów. Prowadzenie edukacji antydyskryminacyjnej. Organizowanie w miejscu pracy, w swoim mieście każdego roku 10 października Światowych Dni Zdrowia Psychicznego lub 7 kwietnia - Światowych Dni Chorego Psychicz- nie, wykorzystując te dni do działań uświadamiających w społeczności.

3. Dołączanie do grupy, instytucji o podobnych celach, np. do Polskiego Stowarzyszenia Pielęgniarek i Pielęgniarzy Psychiatrycznych. Współpraca z konsultantem wojewódzkim lub krajowym w dziedzinie pielęgniarstw psychiatrycznego lub psychiatrii (instytucje te mają wpływ na kształtowanie polityki zdrowotnej poprzez doradztwo w jej tworzeniu i służą wsparciem informacyjnym).

4. Współpraca z organizacjami działającymi na rzecz pacjentów z chorobami psychicznymi i wspierającymi ich rodziny (to umożliwia poznanie codzienności oraz problemów z perspektywy osób chorych psychicznie). Zorientować się, czy w środowisku są aktualnie prowadzone kampanie społeczne, np. „Odmień swoją głowę" [31].

Działania edukacyjne prowadzone w społeczności lokalnej są istotne w celu przełamania oporów przed budową w sąsiedztwie domów pomocy dla chorych psychicznie (większość osób jest przeciwna sąsiedztwu chorych psychicznie (zespół NIMBY - No in my background, czyli: Nie na moim podwórku) [32, 34].

Pielęgniarki zrzeszone w grupy interesów powinny wywierać wpływ na media, protestować za każdym razem przeciwko krzywdzącemu wizerunkowi lansowanemu w środkach masowego przekazu i postulować za przedstawianiem prawdziwego obrazu osoby z problemami psychicznymi w gazetach i telewizji. Media powinny pokazywać częściej, obiektywniej i rzetelnej codzienność osób chorych, które tak jak zdrowi wypełniają role społeczne i zawodowe itp. To tego celu można wykorzystać również media społecznościowe (Youtube, Facebook), gdzie za zgodą pacjentów można umieszczać krótkie filmiki, w których chorzy przedstawiają swoją historie [33, 35].

Istotne $\mathrm{w}$ działaniach antystygmatyzacyjnych jest wdrażanie osób z chorobą psychiczną do pracy zawodowej. Możliwość pracy pomaga choremu w integracji społecznej, w realizacji swoich celów, podwyższeniu własnej samooceny. Współpraca na płaszczyźnie zawodowej z chorym przekonuje społeczeństwo do zmiany stereotypowego postrzegania osób po kryzysie psychicznym. Pracodawcy, którzy mieli możliwość współpracy z osobami po kryzysie psychicznym, postrzegają je jako osoby życzliwe dla innych, skromne (ponad 50\%), osoby otwarte i przyjacielskie (39\%). Większość pracodawców (63\%) chciałaby w przyszłości zatrudnić w swoich firmach chorujących psychicznie [36].

Pielęgniarka w codziennym kontakcie z pacjentem poprzez akceptującą postawę wobec chorego psychicznie zapobiega samostygmatyzacji podopiecznych. W czasie wykonywania czynności zawodowych 
pielęgniarka okazuje szacunek choremu, akceptuje jego słabości, pomaga wykorzystać zasoby pozwalające lepiej funkcjonować w społeczeństwie [37, 38]. Pielęgniarka nawiązuje kontakt terapeutyczny z podopiecznym, aby rozpoznać problemy, znaleźć dla nich rozwiązanie, udziela porad dotyczących specyficznych objawów. Już sam fakt traktowania chorego jako podmiotu równorzędnego $\mathrm{w}$ procesie komunikacji chroni go przed uruchomieniem mechanizmów samostygmatyzacji. Pielęgniarka daje pacjentowi poczucie, że jest partnerem w procesie leczenia i współdecydentem, bez którego nie jest możliwa interwencja. Stopniowo wdraża pacjenta do wykonywania czynności, dobierając stopień trudności do stanu chorego. Takie umiejętności są ważne zwłaszcza dla chorych, którzy chorują na schorzenia psychiczne przyciągające zainteresowanie otoczenia, np. schizofrenię. Poprzez treningi umiejętności społecznych pielęgniarka wyposaża podopiecznego w umiejętności potrzebne do uzyskania przez niego jak największego stopnia autonomii. W czasie indywidualnych kontaktów pielęgniarka diagnozuje deficyty w zakresie umiejętności sprawnego funkcjonowania. Dopiera takie metody pracy z chorym, które są dostosowane do jego możliwości intelektualnych, poznawczych i poziomu funkcjonowania społecznego mogą przynieść oczekiwany rezultat. W oddziaływaniu terapeutycznym pielęgniarka wykorzystuje zasadę optymalnej stymulacji [39]. Stopniowo zwiększa zakres wymagań, jakie stawia pacjentowi na drodze do uzyskania autonomii. Początkowo ilustruje wykonanie jakiejś czynności, następnie prosi o jej wykonanie chorego, korygując jego błędy, aż w końcu pełni funkcję jedynie obserwatora w czasie samodzielnego wykonywania tych czynność przez chorego.

\section{Podsumowanie}

Stereotypowe postrzeganie osób z kryzysem psychicznym jest głęboko zakorzenione w świadomości społecznej. Osoby chorujące na zaburzenia psychiczne powinny stawiać czoło objawom choroby oraz krzywdzącym przekonaniom społecznym. Pielęgniarskie działania przyczyniają się do zmniejszenia stygmatyzacji i jej efektów. Pielęgniarki mogą podejmować działania antystygmatyzujące na trzech płaszczyznach: proteście (przeciwko nieprawdziwemu prezentowaniu osób chorych), edukacji (na temat natury zaburzeń psychicznych, np. dla uczniów, pracowników medycznych, społeczności lokalnej) oraz przeciwdziałaniu samostygmatyzacji.

\section{Piśmiennictwo}

1. Taranowicz I. Rola społeczna chorego. W: Barański J. Piątkowski W (red.). Zdrowie i choroba. Wybrane problemy so- cjologii medycyny. Wrocław: Oficyna Wydawnicza ATUT; 2002. 75-81.

2. Sayce L. Stigma, discrimination and social exclusion: whats in a word? J Ment Health. 1998; 7 (4): 331-343.

3. Schomerus G, Angermeyer MC. Stigmatisierung psychisch Kranker. Psychiatrie up 2 date. 2011; 5(6): 345-356.

4. Moncrieff J, Byrne P, Crawford M. Psychiatria wobec wyzwań: antypsychiatria, ruch użytkowników oraz naznaczenie społeczne. W: Wright P. Stern J. Phelon M (red.). Psychiatria. Wrocław: Urban \& Partner; 2008.149-159.

5. Jackowska E. Stygmatyzacja i wykluczenie społeczne osób chorujących na schizofrenię - przegląd badań i mechanizmy psychologiczne. Psychiatria Polska. 2009; 12 (6): 655-670.

6. Cechnicki A, Bielańska A. Czynniki demograficzno-społeczne i kliniczne a antycypacja i doświadczenie piętna choroby psychicznej. Post Psychiatr Neurol. 2009; 18 (1): 31-41.

7. Trawkowska D, Frąckowiak-Sochańskiej M. Problemy w funkcjonowaniu systemów wsparcia medycznego i społecznego dla osób z zaburzeniami psychicznymi - wnioski z analizy na przykładzie województwa wielkopolskiego. Ann UMCS Sect D. 2017; 30(4): 207-229.

8. Mroczek B, Wroblewska I, Kedzierska A, Kurpas D. Postawy dorosłych Polaków wobec osób chorych psychicznie. Fam Med Primary Care Rev. 2014; 16(3): 263-265.

9. Pratiwi NMS, Zuhriyah L, Supriati L. Exposure to mass media as a dominant factor influencing public stigma toward mental illness based on sunrise model approach. Bel Nur Jour. 2018; 4(2): 232-241.

10. Angermayer MC, Matschinger $\mathrm{H}$. The effect of violent attacks by schizophrenic persons on the attitude of the public towards the mentally ill. Soc Sci Med. 1996; 43 (12): 17-21.

11. Wahl OF. Depictions of mental illnesses in childrens media. J Ment Health. 2003; 12 (3): 249-258.

12. Dyduch A, Grzywa A. Stygmatyzacja i czynniki ją warunkujące na przykładzie stygmatyzacji związanej z chorobą psychiczną. Pol Merkuriusz Lek. 2009; 26 (153): 263-267.

13. Świtaj P. Rola diagnozy psychiatrycznej w procesie stygmatyzacji osób z zaburzeniami psychicznymi. Post Psychiat Neurol. 2009; 18 (4): 377-386.

14. Angermeyer MC, Holzinger A, Carta MG, Schomerus G. Biogenetic explanations and public acceptance of mental illness: systematic review of population studies. BrJ Psychiatrie. 2011; 199: 367-372.

15. Crisp AH, Gelder MG, Rix S, Meltzer HI, Rowlands OJ. Stigmatisation of people with mental illnesses. Br J Psychiatry. 2000; 177: 4-7.

16. Schomerus G, Schwahn C, Holzinger A, Corrigan PW, Grabe HJ, Carta MG, Angermeyer MC. Evolution of public attitudes about mental illness: a systematic review and metaanalysis. Acta Psychiatr Scand. 2012; 125: 440-452.

17. Schomerus G, Angermeyer MC. Do attitudes towards persons with mental illness worsen during the course of life? An age-period-cohort analysis. Acta Psychiatr Scand. 2015; 132: 357-364.

18. Omyła-Rudzka M. Stosunek do osób chorych psychicznie. Warszawa: Centrum Badania Opinii Społecznej. 2012; 3-15.

19. Babicki M, Kotowicz K, Piotrowski P, Stramecki F, Kobyłko A, Rymaszewska J. Obszary stygmatyzacji i dyskryminacji osób chorujących psychicznie wśród respondentów internetowych w Polsce. Psychiatr. Pol. 2018; 52(1): 93-102. 
20. Corrigan PW. Mental Health Stigma as Social Attribution: Implications for Research Methods a Attitude Change. Clin Psychol Sci Pract. 2000; 7: 48-67.

21. Kmieciak B. Choroba psychiczna - cierpienie, które zmieniło prawo. Ethics in Progress. 2014; 5: 115-128.

22. Link BG, Phelan JC. Conceptualizing stigma. Ann Rev Sociol. 2001; 27: 363-385.

23. Arboleda-Florez J, Sartorius N. Understanding the stigma of mental illness. West-Sussex: J. Wiley\&Sons Ltd. The Atrium Southern Gate; 2008. 3-35.

24. Wciórka B, Wciórka J. Sondaż opinii publicznej: społeczny obraz chorób psychicznych i osób chorych psychicznie w roku 2005. Post Psychiat Neurol. 2006; 15 (4): 255-267.

25. Bronowski P. Stygmatyzacja psychiatrów. Psychiatr Dypl. 2013; 10(1): 45-51.

26. Gore Ch, Figueiredo JB. Wykluczenie społeczne i polityka przeciwdziałania ubóstwu. Probl Poli Społ. 2003; 5: 1-19.

27. Jankowska M. Osobowościowe i społeczno-kulturowe uwarunkowania postaw wobec osób niepełnosprawnych. Badania młodzieży trzecich klas gimnazjalnych. Kwartalnik Naukowy Fides et Ratio. 2015; 4(24): 202-227.

28. Rezner A, Rezner W, Kosecka J. Edukator zdrowia w podstawowej opiece zdrowotnej jako szansa na podniesienie poziomu promocji zdrowia i profilaktyki w Polsce. Probl Hig Epidemiol. 2013; 94(3): 407-412.

29. Kunecka D, Musiał B. The authority of the nurse as an educator. Pomeranian J Life Sci. 2017; 63(3): 67-71.

30. Pabiś M, Ślusarska M, Jarosz MJ, Zarzycka D, Dobrowolska B, Brzozowska A. Kompetencje pielegniarek w zakresie edukacji zdrowotnej w polskim systemie opieki medycznej. Pielęg XXI w. 2010; 3-4: 75-84.

31. Usher K, Grigg M. Pielęgniarstwo psychiatryczne. Problemy i kierunki rozwoju. Genewa: INC; 2009. 3-36.

32. Sartorius N, Gaebel W, Cleveland HR, Stuart H. Akiyama T. i wsp. Wytyczne WPA: jak przeciwdziałać stygmatyzacji psychiatrii i psychiatrów. Post Psychiat Neurol. 2011; 20 (2): 89-104.

33. Angermayer MC, Matschinger $\mathrm{H}$. The effect of violent attacks by schizophrenic persons on the attitude of the public towards the mentally ill. Soc Sci Med. 1996; 43 (12): 17-21.
34. Ślusarczyk J, Kowalczyk R, Barbaro B. Seksualność pacjentów chorujących na schizofrenię. Prz Seksuol. 2011; 7 : 4-9.

35. Schulz M, Zuamboni G, Lohr M. Die zweite Krankheit. Die Schwester Der Pfleger. 2016; 1: 2-6.

36. Bartosiewicz-Niziołek M. Wsparcie osób z zaburzeniami psychicznymi na rynku pracy cz. II. Warszawa: PEFRON; 2013. 2-126.

37. Freidl M, Piralic Spitzl S, Prause W, Zimprich F, Lehner Baumgartner E, Baumgartner C, Aigner C. The stigma of mental illness: Anticipation and attitudes among patients with epileptic, dissociative or somatoform pain disorder. Int Rev Psychiatry. 2007; 19(2): 123-129.

38. Wilczewska L, Ciszkowska-Kreft M. Udział pielęgniarki w rehabilitacji psychiatrycznej. Prob Pielęg. 2010; 4: 483-489.

39. Pieta P. Sposoby rozwiazywania problemów dnia codziennego wynikających z doświadczenia przewlekłej choroby psychicznej - schizofrenii. Pielęg Pol. 2017; 3(65): 537-543.

Artykuł przyjęty do redakcji: 28.02.2019.

Artykuł przyjęty do publikacji: 04.07.2019.

Źródło finansowania: Praca nie jest finansowana z żadnego źródła. Konflikt interesów: Autor deklaruje brak konfliktu interesów.

\section{Adres do korespondencji:}

Piotr Wojda

Wilhelm-Griesinger-Straße 23

51109 Köln

telefon $+49(0) 221 / 8993-0$

telefax $+49(0) 221 / 897-664$

e-mail: askot8@wp.pl, klinik-koeln@lvr.de

LVR-Klinik Köln Akademisches Lehrkrankenhaus der Universität zu Köln 